\title{
Risk Analysis of China's Foreign Direct Investment
}

\author{
Bowen Zhang \\ Guizhou Institute of Social Construction, Guizhou University of Finance and economics, Guizhou, China; \\ 550025 \\ zbwmjr@163.com
}

Keywords: Foreign direct investment, Risk prevention, Security capability construction, National strategic security.

\begin{abstract}
With the proposed and implemented "Belt and the Road" initiative, China's foreign direct investment enters "the fast lane". Foreign direct investment scale and high growth reflects that our country has the strong momentum of economic development. However, due to blind fashion international investment (market risk) and lack of political, legal, cultural and other aspects of the risk estimation, the corresponding risk prevention capacity and safety problems have become increasingly prominent. Restricted along the road construction, national security strategy especially has an extremely adverse impact on economic security. Further analysis, based on the above risk problems, explores two main reasons: subjective and objective. To study and solve the problem of risk prevention and security capability construction of foreign direct investment, it is necessary, from a historical perspective, to find out some specific ideas and methods from various practical influences or constraints.
\end{abstract}

\section{Introduction}

In recent years, China has been actively encouraging enterprises to " go out" to make the best use of " two markets" and " two resources" at home and abroad. Especially with the proposal and implementation of the " the belt and road initiative" initiative, China's foreign direct investment has entered the " fast track". According to statistics from the Ministry of Commerce, non-financial foreign direct investment by Chinese enterprises was 90.17 billion US dollars in 2013 - 2015, 102.89 billion US dollars and 118.02 billion US dollars respectively, setting a new record of 1701 billion US dollars by 2016. The large-scale and high-growth foreign direct investment certainly reflects the strong momentum of China's export-oriented economic development, but due to the blind pursuit of international investment ( market risk ) and insufficient risk estimation in political, legal and cultural aspects, the corresponding problems of risk prevention and security capacity-building have become increasingly prominent, becoming a major security hidden danger that affects the effective implementation of the enterprise's " going global" strategy, severely restricting the construction of " the belt and road initiative" and having extremely adverse impact on national strategic security, especially economic security. After careful analysis, the reasons for the above-mentioned problems of FDI risk concentration, risk prevention and security capacity-building are various, and various subjective or objective factors must be specifically analyzed and deeply discussed, and ideas and methods for solving the problems must be explored from the historical investigation and current situation analysis of China's surrounding security environment and security strategy.

\section{The Subjective Reason for the Risk Prevention and Security Capacity Building of Foreign Direct Investment}

From the subjective point of view, the reason for the risk prevention and security capacity building of foreign direct investment is the lack of experience in foreign direct investment and the lack of national strategic security awareness and international investment risk awareness. In the past, China 
opened up to the outside world mainly for the purpose of introducing foreign capital and technology, and economic development paid more attention to promoting the improvement of domestic people's livelihood and market prosperity through growth. However, with the reform and opening-up and the further development of the socialist market economy, the domestic livelihood issues have been fundamentally improved and have already entered the buyer's market through the era of shortage economy and accumulated a large amount of foreign exchange reserves. Since the global financial crisis in 2008, due to the objective factors of relatively cheap asset prices in major western countries and relatively small impact on domestic enterprises, China's demand for foreign direct investment and international operation of enterprises has been greatly stimulated, and some enterprises that have grown up over the years have implemented the " going out" strategy. In particular, the proposal and implementation of the " the belt and road initiative" initiative have made the enterprise's " going out" strategy fit in with the new strategy of national construction of " the belt and road initiative" and all-round opening to the outside world. The introduction of various foreign direct preferential policies and convenient conditions has directly promoted foreign direct investment and export-oriented economic development. Under this background, how to rationally choose the international investment field, scientifically assess the risks of enterprises' foreign direct investment, and how to implement the business philosophy of " going out" strategy in line with the new strategy of national construction " the belt and road initiative" and all-round opening to the outside world at the level of investment planning and project landing has not received due attention and attention due to the lack of international enterprise management and management talents with a global vision. In the final analysis, compared with the major western countries, China's foreign direct investment and international operation of enterprises have only just started, and there is a serious lack of relevant experience and necessary talent reserves. This is the root cause of the problem of risk prevention and security capacity building.

\section{The Subjective Reason for the Risk Prevention and Security Capacity Building of Foreign Direct Investment}

From the objective point of view, the reason for the risk prevention and security capacity building of foreign direct investment is mainly due to the inherent risk factors and uncertainties of FDI. Here, it mainly involves various risks and uncontrollable factors from the market, as well as risks and uncertainties in foreign political, legal, cultural and other fields involved in foreign direct investment. For our country, the neighboring countries and the countries along the Silk Road are basically developing countries and have historically been the targets of the Cold War confrontation regions and major powers. Today, the problems left over from the Cold War, especially ethnic and religious disputes, have a long history and are complicated, leading to frequent wars and poor people's livelihood, and lack the necessary political and economic environment and financial and technical conditions for economic development. Under such circumstances, direct investment to neighboring countries and countries along the Silk Road is bound to face such and such risks and challenges, and the corresponding enterprises will also fall into various difficulties in their international operations, thus highlighting their risk prevention and security capacity building issues. Since the above risks and uncertainties exist objectively, they must be correctly understood and grasped. The concentration of foreign direct investment risks, objectively speaking, lies not only in the objective existence of risks themselves, but also in the lack of information feedback and intelligence support related to risks. As Sha Zukang pointed out at the Pacific " the belt and road initiative" Forum, the most important task of our embassy should not be to welcome the reception work, but to " first clarify the situation in the country, especially to collect the customs, laws and economic development of the country" and really come up with a guiding " the belt and road initiative" investment manual. In short, the lack of information feedback and intelligence support related to OFDI risk is an important reason for the above-mentioned concentration of OFDI risk. 


\section{From the Perspective of Historical Sources, Discussing the Question of Risk Prevention and Security Capacity Building of Foreign Direct Investment}

From the perspective of historical sources, it is necessary to understand the origin of the above-mentioned risk factors and uncertainties in foreign direct investment in order to solve the problems of risk prevention and security capacity-building in foreign direct investment. All kinds of risk factors and uncertainties from reality are essentially products of history. Here, in order to understand the origin of the risk factors and uncertainties of foreign direct investment, it is necessary to conduct a longitudinal historical investigation of China's surrounding security environment and security strategy, analyze the internal relationship between China's surrounding security environment and security strategy, reveal the internal relationship between security strategy and national defense, military affairs, diplomacy and economic development, and provide experience or historical enlightenment for understanding and grasping the dialectical relationship between security and risk, and finally solving the problems of risk prevention and security capacity-building of foreign direct investment. That is to say, in order to solve the problems of risk prevention and security capacity-building of foreign direct investment, it is necessary to take these problems into consideration from a historical perspective and "search for historical causality for what is happening". After all, without historical investigation, it is impossible to understand and grasp the internal law of the evolution and development of China's surrounding security environment and security strategy, and it is impossible to make a reasonable theoretical interpretation of the above-mentioned practical problems. Of course, historical investigation is only a means to understand the reality and explain the current situation of the problem. What it needs to explain is how the past has developed to the present situation. The study of the real problem is only enlightening and cannot lead to the final solution of the problem. The final solution to practical problems such as foreign direct investment risk prevention and security capacity building also needs to be studied and discussed from the concrete analysis of many factors that affect or restrict the current security environment and security strategy around China.

\section{From the Perspective of Reality, Discussing the Question of Risk Prevention and Security Capacity Building of Foreign Direct Investment}

From the perspective of reality, to solve the problems of risk prevention and security capacity building of foreign direct investment, we need to accurately grasp the new changes in China's surrounding security environment and security strategy, and specifically and deeply analyze and discuss the main factors that affect or restrict the current China's surrounding security environment and security strategy. In this way, it is possible to further reveal the internal relationship between national strategic security and foreign direct investment risk, and provide necessary practical basis for finally solving the problems of risk prevention and security capacity - building, and putting forward policies and suggestions for maintaining and realizing national strategic security. In fact, with the constant expansion of foreign direct investment and the major adjustment of international strategic pattern, a series of new changes have taken place in China's surrounding security environment. At present, not only has the construction of "the belt and road initiative" become a new thinking, new vision and new strategy for China's peaceful rise in the 21st century, but maritime security has also begun to become increasingly prominent, with increasing challenges and threats to the surrounding security. Further analysis shows that the main factors influencing or restricting China's surrounding security environment and security strategy include American factors, Japanese factors, Russian factors, ASEAN factors, Indian factors and many other international factors, but the most important and crucial one is American factors. The complexity and uncertainty of international factors objectively increase the political risk of China's foreign direct investment, making it more difficult for enterprises to operate internationally. Compared with domestic enterprises, the biggest problem for enterprises that have already implemented the "going global" strategy in international operation is the uncertainty of the investment environment in the country, especially the political, 
legal, economic and cultural conditions, as well as the resulting disorientation of business activities or blind decision - making. For example, in the process of foreign direct investment in sturm und drang in recent years, there has been an irrational tendency to invest abroad in such fields as real estate, hotels, studios, entertainment industry, sports clubs, etc. In 2015 and 2016 alone, the funds for acquiring overseas teams amounted to 15 billion yuan, and most of these funds came from domestic high-leverage financing. As a result, irrational foreign investment by enterprises inevitably involves huge risks, including financial crisis caused by high corporate responsibility rate, transfer of assets under the packaging of foreign direct investment, international balance of payments imbalance caused by rapid outflow of cross-border capital, decline in foreign exchange reserves and market main body panic caused by changes in RMB exchange rate. It can be seen that solving the problem of risk prevention and security capacity-building of foreign direct investment is not only an enterprise's own business problem, but also a major political issue involving national financial security and the security of foreign enterprises and foreign investment. We must start with multiple channels and multiple fields such as national financial supervision, industry governance, industrial policy guidance and strengthening internal management of enterprises, optimizing investment decisions, and incorporate them as far as possible into the overall framework of national security system construction to prevent and resolve relevant risks and ensure the security of foreign enterprises and foreign investment.

\section{Summary}

There are subjective and objective reasons that lead to the accumulation of foreign direct investment risks and the problems of risk prevention and security capacity building in China. The subjective reason is the lack of foreign direct investment experience and the lack of national strategic security awareness and international investment risk awareness. Objectively, there are not only inherent risk factors and uncertainties in foreign direct investment, but also the lack of risk-related information feedback and intelligence support. In order to solve the problems of risk prevention and security capacity-building of foreign direct investment, besides having a historical perspective, understanding the origin of risk factors and uncertainty of foreign direct investment, and taking these problems into consideration comprehensively, we should also accurately grasp the new changes in China's surrounding security environment and security strategy, and discuss them from the concrete analysis of many factors that affect or restrict the current China's surrounding security environment and security strategy, so as to provide the necessary practical basis for finally solving the problems of risk prevention and security capacity-building of foreign investment and putting forward policies and suggestions for maintaining and realizing the national strategic security. That is to say, only by digging deeply into the historical investigation and current situation analysis of China's surrounding security environment and security strategy can we find the way to solve the above problems.

\section{Acknowledgements}

This research was financially supported by the Fundamental Research Funds for Guizhou Province Higher School Teaching Content and Curriculum System Reform Project and Guizhou University of Finance and Economics Teaching Reform and Quality Construction Projec " Teaching Reform and Construction of China's Surrounding Security Environment and Security Strategy".

\section{References}

[1] Information on http://www.hao123.com/mid/ 51181052958380962? key=\&from=tuijian\&pn=2.

[2] Information on http://news.ifeng.com/dacankao/Shazukang/1.shtml.

[3] [US]Thomas Pikov, John Colbert; Luo Yue Compiled. The Great Change of Military Education in China, Financial Abstracts, vol.1, 2009. 
[4] Xutian Xia, Li Qiqi. Curbing irrational foreign investment, 21st century business herald, 2017-7-21. 